\title{
Patterns of changes in proteins in the peritoneal fluid of women during the periovulatory phase of the menstrual cycle
}

\author{
P. X. J. M. Bouckaert, J. L. H. Evers, W. H. Doesburg, L. A. Schellekens, \\ P. H. Brombacher and R. Rolland \\ Department of Obstetrics and Gynaecology, Sint Annadal Ziekenhuis, The University of Limburg, \\ P.O. Box 1918,6201 BX Maastricht, The Netherlands
}

\begin{abstract}
Summary. During a laparoscopy that was performed between Day -6 and Day +9 of the cycle as related to the day of the LH peak (Day 0), the peritoneal fluid of 100 healthy female volunteers of proven fertility was collected and analysed. Peritoneal fluid volume and concentrations of total protein, albumin, $\alpha_{1}-, \alpha_{2^{-}}, \beta$ - and $\gamma$-globulins, IgA, IgG, IgM, haptoglobulin, acid- $\alpha_{1}$-glycoprotein, $\alpha_{1}$-antitrypsin, $\alpha_{2}$-macroglobulin, $\mathrm{C}_{3^{-}}, \mathrm{C}_{4^{-}}$and $\mathrm{C}$-reactive protein were determined. The peritoneal fluid volume and the concentrations of most proteins analysed showed an increase during the post-ovulatory phase of the period investigated. The peritoneal fluid:serum ratio of each individual protein showed a significant inverse correlation with its molecular weight. This confirms the assumption that peritoneal fluid is mainly an exudation product, most probably of ovarian origin.
\end{abstract}

\section{Introduction}

In 1922 Novak reported the presence of fluid in the pouch of Douglas (or cul-de-sac) during clinical observations. The amount of fluid appeared to be related to the phase of the menstrual cycle. These findings were corroborated in subsequent studies by other investigators (Bissell, 1932; Doyle, 1951; Maathuis, Van Look \& Michie, 1978; Koninckx, Renaer \& Brosens, 1980a). Most authors reported an increase in volume during the preovulatory phase with a maximum in the early luteal phase and a decrease in the late luteal phase of the cycle. Only small amounts of fluid were collected in male subjects (Novak, 1922; Maathuis et al., 1978). In women without Fallopian tubes and in women without a uterus the volume of the peritoneal fluid did not differ significantly from that of 'normal' women; pelvic varicosis, a discernible corpus luteum or an ovulation stigma did not affect the volume of peritoneal fluid (Koninckx et al., 1980a).

The number of studies concerning the protein composition of the peritoneal fluid is limited. Maathuis, Houx, Bastiaans \& Mastboom (1973) provided a qualitative survey of the proteins present and Maathuis et al. (1978) reported a mean ( \pm s.d.) total protein concentration in peritoneal fluid of $42 \cdot 2 \pm 6 \cdot 0 \mathrm{~g} / \mathrm{l}$. The total protein concentration did not change during the menstrual cycle. Koninckx et al. (1980a) demonstrated a cyclic pattern for the total protein concentration, with a significant increase during the luteal phase of the menstrual cycle. From this study it was concluded that peritoneal fluid is mainly an exudation product of the ovaries.

The aim of the present study was to investigate whether this conclusion about the peritoneal fluid being an exudation product of mainly ovarian origin could be confirmed by an analysis of its protein composition.

\section{Materials and Methods}

A group of 100 women, all between 20 and 45 years of age, was investigated. They were referred to 
our hospital for a laparoscopic sterilization procedure. All were healthy and none was using oral contraceptives, or an intrauterine contraceptive device. Only women with a normal cycle length according to Treloar, Boynton, Behn \& Brown (1967), between 23 and 32 days, were included.

During the cycle 7 blood samples were withdrawn, starting 4 days before the expected time of ovulation. Samples were taken every other day except during the period of laparoscopy. Blood samples were then collected on the day of laparoscopy, before inducing general anaesthesia and on the previous and subsequent day. During laparoscopy peritoneal fluid samples were collected as described before (Bouckaert, van Wersch, Schellekens, Evers \& Rolland, 1984). Blood and peritoneal fluid samples were centrifuged. The supernatants were frozen and stored at $-70^{\circ} \mathrm{C}$ until assayed. The day of the laparoscopy was related to the day of the LH peak (Day 0) as indicated by Hilgers, Abraham \& Cavanagh (1978).

The LH concentration in serum was measured by radioimmunoassay (Farmos Diagnostica, Finland). The progesterone level in serum was also determined by radioimmunoassay but without the usual extraction technique (Farmos Diagnostica, Finland).

Total protein concentration was measured in serum as well as in peritoneal fluid by means of the biuret reaction (Richterich, 1971) using a Cobas Bio Centrifugal Analyzer (Hoffman-La Roche, Switzerland). Albumin, $\alpha_{1^{-}}, \alpha_{2^{-}}, \beta$ - and $\gamma$-globulins were measured in serum and peritoneal fluid by electrophoresis, making use of the differences in negative charge (Kaplan \& Savory, 1965). IgA, IgG, IgM, haptoglobulin, acid- $\alpha_{1}$-glycoprotein, $\alpha_{1}$-anti-trypsin, $\alpha_{2}$-macroglobulin, $\mathrm{C}_{3^{-}}, \mathrm{C}_{4^{-}}$and $\mathrm{C}$-reactive protein levels were measured in the peritoneal fluid by means of a radial-immunodiffusion technique based on the radial diffusion and precipitation of a protein with its corresponding monospecific antiserum in an agar gel layer (M-Partigen and LC-Partigen immunodiffusion plates: Behring Institut, Amsterdam, The Netherlands) (Mancini, Carbonara \& Heremans, 1965). The interassay variabilities $(\%)$ for the proteins that were analysed were $1 \cdot 8$ for total protein, $2 \cdot 5$ for $\operatorname{IgA}, 2 \cdot 3$ for IgG, 3.0 for IgM, 4.3 for haptoglobulin, 2.3 for acid- $\alpha_{1}$-glycoprotein, 3.9 for $\alpha_{1}$-antitrypsin, $7 \cdot 5$ for $\alpha_{2}$-macroglobulin, $5 \cdot 5$ for $C_{3}$-protein and $4 \cdot 6$ for $C_{4}$-protein.

The period of the cycle that was investigated (from Day -6 until Day +9 ) was divided into 7 phases. The results are expressed in terms of means \pm s.e.m.

Statistical methods. To investigate the existence of a cycle-dependent pattern the Kruskal-Wallis test was used. Only when a cycle dependency was likely $(0.05<P<0.10)$ or proven $(P<0.05)$ were the results of each phase of the period investigated compared with each other using Wilcoxon's two-sample test to detect statistical differences $(P<0.05)$.

\section{Results}

The peritoneal fluid volume demonstrated a cycle-dependent pattern during the period investigated $(P<0.003)$. The volume shows a significant increase between cycle days $-1 / 0$ and $+1 /+2$. The difference between the results in the first three phases and those in the last four phases was significant (Fig. 1).

The concentrations of proteins determined in serum failed to show a cycle-dependent pattern. The peritoneal fluid concentrations of total protein $(P<0.001)$, albumin $(P<0.001)$, $\alpha_{1}$-globulin $(P<0.05)$ and $\beta$-globulin $(P<0.006), \alpha_{1}$-anti-trypsin $(P<0.01), \mathrm{C}_{3}$-protein $(P<0.001)$ and $\mathrm{C}_{4}$-protein $(P<0.02)$ showed a cycle-dependent pattern. For the concentrations of IgG and acid- $\alpha_{1^{-}}$ glycoprotein, a cycle-dependent pattern was probable $(P<0.06$ and $P<0.06$, respectively). No cycle-dependent pattern could be demonstrated for the concentrations of $\alpha_{2}$ - and $\gamma$-globulins, $\operatorname{IgA}$, IgM, haptoglobulin and $\alpha_{2}$-macroglobulin. C-reactive protein was not detectable in any of the peritoneal fluid samples.

The total protein concentration steadily increased from the start until the end of the period investigated. The values from the first four phases were significantly lower than those in the last 


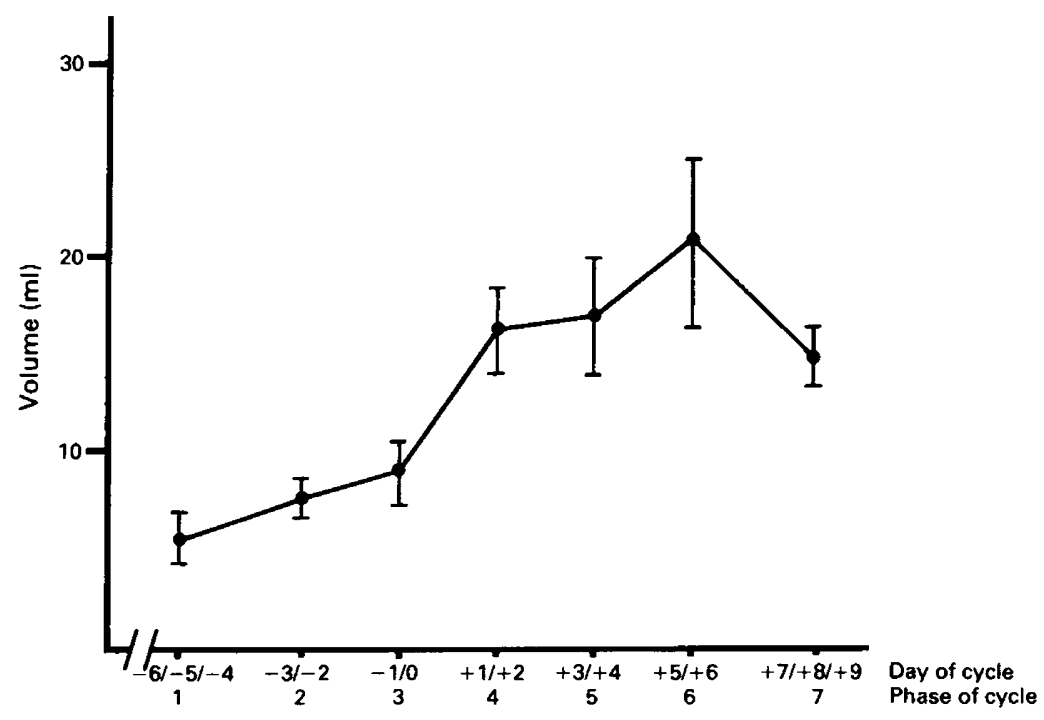

Fig. 1. Pattern of change of the peritoneal fluid volume during the periovulatory phase of the menstrual cycle. (Values are mean \pm s.e.m.)

three phases $(P<0.05)$ (Fig. 2). The pattern of the albumin concentration fully corresponded with that obtained for the total protein concentration. After an initial decrease until Day $-1 / 0$ the $\alpha_{1}$-globulin concentration started to increase to a maximum at the end of the period investigated. The difference between values on Day $-1 / 0$ and the last phase of the period investigated was significant $(P<0 \cdot 003)$. The $\beta$-globulin concentration started to rise after Day $-3 /-2$ until a maximum was reached on Day $+5 /+6$. The differences between the concentrations on Days $-3 /-2$ and $-1 / 0$ and the last three phases investigated were significant $(P<0.05)$. After Day $-1 / 0$ the $\alpha_{1}$-antitrypsin concentration showed an increase until the end of the period investigated. The results measured on Days $-1 / 0$ and $+1 /+2$ differ significantly from those in the following phases $(P<0.05)$. The $\mathrm{C}_{3}$-protein concentration showed an irregular rise from the beginning of the period investigated until the end. The results in the first three phases were significantly lower than those measured in the last four phases $(P<0.05)$ except for phase $5($ Day $+3 /+4)$.

Concentrations of $\mathrm{C}_{4}$-protein remained more or less stable until Day $-1 / 0$. After a rise on Day $+1 /+2$ concentrations once again remained stable but on a higher level. The IgG concentration showed a rise from the start of the period investigated until a maximum was reached on Day $+5 /+6$. The values in the first two phases were lower than those in the last three phases $(P<0.05)$. The acid- $\alpha_{1}$-glycoprotein concentration remained stable after an increase on Day $-3 /-2$. The results in the first phase (Days $-6 /-5 /-4$ ) were significantly lower than those in the following phases of the period investigated $(P<0.05)$, with the exception of values on Day $-1 / 0$. The mean values of the concentrations of single proteins in serum and peritoneal fluid, as determined for the period investigated as a whole, are given in Table 1. For those proteins determined by radial-immunodiffusion, serum concentrations of a population of blood donors was used to calculate the peritoneal fluid:serum ratio.

When the results of the peritoneal fluid:serum ratio for the single proteins were plotted against their molecular weights on a semilogarithmic scale, a significant inverse relation appeared to exist $(r=0.83 ; P<0.05)$ : the higher the molecular weight of a given protein, the lower its concentration in the peritoneal fluid (Fig. 3). 

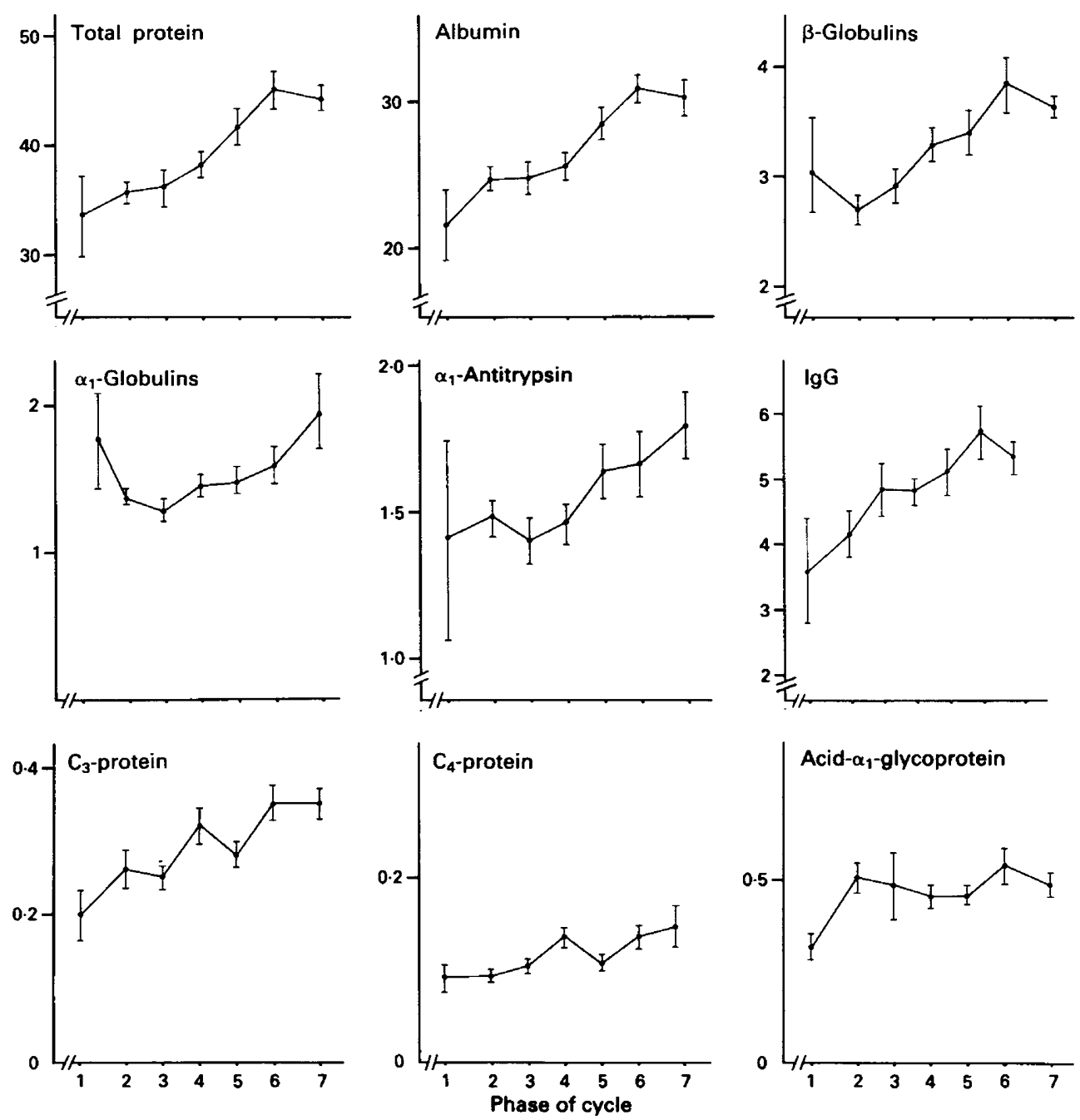

Fig. 2. Patterns of change in the concentrations (mean \pm s.e.m., $g / 1$ ) of several proteins during the periovulatory phase of the menstrual cycle (mean \pm s.e.m.) as determined by biuret reaction, electrophoresis, and radial-immunodiffusion. The cycle phases $1,2,3,4,5,6$ and 7 corresponded with the following days of the cycle: $-6 /-5 /-4,-3 /-2,-1 / 0,+1 /+2$, $+3 /+4,+5 /+6$ and $+7 /+8 /+9$.

\section{Discussion}

The ovaries determine the amount of peritoneal fluid and its variation during the menstrual cycle (Koninckx et al., 1980a). Contributions from the ovaries to the peritoneal fluid volume can either result from exudation from the ovarian capillaries, from transudation and exudation from the antrum of the preovulatory follicle, or from release of the follicular fluid into the abdomen during ovulation. Rupture of the follicle during ovulation will contribute to the total amount of peritoneal fluid. Coulam, Hill \& Breekle (1982) observed during an ultrasonic investigation an increase of the fluid volume in the cul-de-sac after ovulation. However, deposition of the follicular contents into the abdominal cavity at ovulation cannot account for the persisting high peritoneal fluid volumes 
Table 1. Serum and peritoneal fluid concentrations $(\mathrm{g} / \mathrm{l})$ of several proteins and their ratios calculated for the period investigated as an whole

\begin{tabular}{lcrc}
\hline & $\begin{array}{c}\text { Peritoneal } \\
\text { fluid }\end{array}$ & Serum & Ratio \\
\hline Total protein & $39 \cdot 5$ & $68 \cdot 0$ & $0 \cdot 58$ \\
Albumin & $27 \cdot 6$ & $40 \cdot 2$ & $0 \cdot 69$ \\
$\alpha_{1}$-Globulins & $1 \cdot 4$ & $2 \cdot 5$ & $0 \cdot 56$ \\
$\alpha_{2}$-Globulins & $2 \cdot 0$ & $6 \cdot 3$ & $0 \cdot 32$ \\
$\beta$-Globulins & $3 \cdot 2$ & $6 \cdot 9$ & $0 \cdot 48$ \\
$\gamma$-Globulins & $5 \cdot 6$ & $11 \cdot 6$ & $0 \cdot 48$ \\
IgG & $5 \cdot 50$ & $11 \cdot 7$ & $0 \cdot 47$ \\
IgA & $0 \cdot 75$ & $2 \cdot 3$ & $0 \cdot 33$ \\
IgM & $0 \cdot 29$ & $1 \cdot 6$ & $0 \cdot 18$ \\
Haptoglobulin & $0 \cdot 48$ & $2 \cdot 0$ & $0 \cdot 24$ \\
Acid- $\alpha_{1}$-glycoprotein & $0 \cdot 44$ & $0 \cdot 9$ & $0 \cdot 47$ \\
$\alpha_{1}$-Antitrypsin & $1 \cdot 60$ & $3 \cdot 0$ & $0 \cdot 53$ \\
$\alpha_{2}$-Macroglobulin & $0 \cdot 64$ & $2 \cdot 9$ & $0 \cdot 22$ \\
C $_{3}$-protein & $0 \cdot 29$ & $1 \cdot 1$ & $0 \cdot 25$ \\
C $_{4}$-protein & $0 \cdot 11$ & $0 \cdot 35$ & $0 \cdot 31$ \\
\hline
\end{tabular}

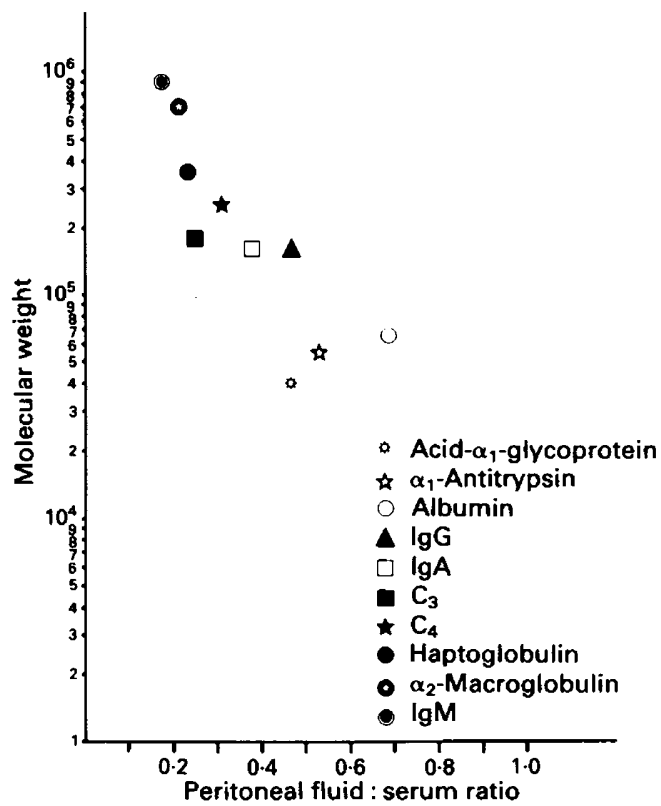

Fig. 3. The relation between the molecular weight and the peritoneal fluid:serum ratio of several proteins $(r=-0.83 ; P<0.05)$.

throughout the luteal phase of the cycle. In patients with a failure of the luteinizing follicle to rupture, Koninckx et al. (1980b) found peritoneal fluid volumes which did not differ significantly from those in ovulating women. They concluded that the contribution of fluid from the rupturing follicle can only be of minor importance to the increase of the peritoneal fluid volume around the time of ovulation. In the preovulatory phase of the cycle the dimensions of the Graafian follicle increase rapidly. The intrafollicular pressure, however, does not increase (Stähler, Spätling, Daume 
\& Buchholz, 1977), notwithstanding the fact that an increase in colloid-osmotic pressure is observed (Zachariae \& Jensen, 1958). This renders a significant contribution of transudation and exudation from the intact ovulatory follicle into the abdominal cavity virtually impossible. The vast difference between steroid hormone concentrations in follicular fluid (McNatty \& Baird, 1978) and preovulatory peritoneal fluid (Koninckx et al., 1980a) further emphasizes the improbability of a significant contribution of antral fluid to the volume of fluid in the peritoneal cavity during this phase of the menstrual cycle.

The present results confirmed those of previous studies that the volume of peritoneal fluid increases from the follicular phase to the luteal phase of the menstrual cycle. The highest values were recorded on Days $+5 /+6$, after ovulation. The relatively high total protein content of peritoneal fluid (55-67\% of serum levels) accentuates its origin as an exudation product. The concentrations of the various proteins and protein fractions in the peritoneal fluid depend predominantly on the hydrostatic pressure in the ovarian capillary network, the diameter of the endothelial gaps, the electrical charge of the individual proteins, and their molecular weight. Proteins with a low molecular weight pass through the capillary wall more easily than those with a high molecular weight. Thus proteins with a low molecular weight such as albumin, antitrypsin and $\alpha_{1}$-glycoprotein have a higher peritoneal fluid:serum ratio than do proteins with a high molecular weight such as $\alpha_{2}$-macroglobulin, haptoglobulins and the transferrin content of $\beta$-globulins. The high molecular weight $\mathrm{C}_{3}$ - and $\mathrm{C}_{4}$-proteins, also components of the $\beta$-globulin fraction, can exert no significant influence upon the peritoneal fluid:serum ratio of the total $\beta$-globulin fraction because of their low concentrations. IgG, the most important component of the $\gamma$-fraction, has a molecular weight between that of albumin and haptoglobulin. Its peritoneal fluid:serum ratio lies between those of albumin and haptoglobulin. The molecular weight of $\operatorname{IgM}$ is 5 times higher than that of IgG. Its peritoneal fluid:serum ratio is very low. Plotting the molecular weights of the peritoneal proteins on a semilogarithmic scale against their peritoneal fluid:serum ratios (Fig. 3) demonstrates that these ratios are related to the respective molecular weights $(r=0.83 ; P<0.05)$. In a related study (Bouckaert et al., 1984) we showed that clotting factor VIII, which has a molecular weight of more than twice that of IgM, is absent from peritoneal fluid. A similar relationship has been demonstrated for the proteins in follicular fluid (Andersen, Krøll, Byskov \& Faber, 1976). A striking similarity exists between follicular fluid:serum ratios found by Edwards (1974) and the peritoneal fluid:serum ratios for the same proteins in the present investigation (Table 2).

In the preovulatory phase of the cycle oestrogens stimulate the circulation in the theca capillaries of the dominant follicle, which increases rapidly (Scanes, Mozelic, Kavanagh, Merill \& Rabii, 1982 ), resulting in an increase of exudation. Concentrations of progesterone and oestradiol-17 $\beta$ in the peritoneal fluid reach a peak on Days $+1 /+2$, when the corpus luteum reaches its maximum stage of development during the reproductive cycle. Just before ovulation the follicle receives the

Table 2. Follicular fluid:serum ratio as reported by Edwards (1974) and the peritoneal fluid:serum ratio as calculated from the present results

\begin{tabular}{lcc}
\hline & $\begin{array}{c}\text { Follicular fluid: } \\
\text { serum ratio }\end{array}$ & $\begin{array}{c}\text { Peritoneal fluid: } \\
\text { serum ratio }\end{array}$ \\
\hline Albumin & 0.58 & 0.69 \\
Acid- $\alpha_{1}$-glycoprotein & 0.50 & 0.47 \\
IgG & 0.45 & 0.47 \\
IgA & 0.36 & 0.33 \\
IgM & 0.12 & 0.18 \\
Haptoglobulin & 0.41 & 0.24 \\
$\alpha_{2}$-Macroglobulin & 0.12 & 0.22 \\
\hline
\end{tabular}


largest volume of blood per unit time and has capillaries which are more permeable than those of other follicles (Moor, Hay \& Seamark, 1975). The vascularity of the freshly formed corpus luteum is low, and so also its exudative potential (Peters \& McNatty, 1980). Therefore, in this phase of the cycle the increase in peritoneal fluid volume can only be attributed to the addition of follicular fluid due to rupture of the Graafian follicle. Soon after ovulation, however, the vascularization of the corpus luteum increases to reach a maximum during the mid-luteal phase. At this time oestradiol-17 $\beta$ concentrations in the corpus luteum reach a maximum, exerting a vasodilating effect on the newly formed capillaries, which facilitates exudation (Swanston, McNatty \& Baird, 1977). The continuing high volumes of peritoneal fluid throughout this part of the luteal phase most probably result from this increase in exudation from the corpus luteum capillaries. Subsequently, endothelial gaps widen, proteins leave the capillaries selectively, according to their molecular weight, and peritoneal fluid accumulates due to the resulting increase in colloid-osmotic pressure.

In the late luteal phase the production of steroid hormones in the corpus luteum decreases, the size of the endothelial gaps diminishes and the blood flow through the corpus luteum capillaries decreases (Swanston et al., 1977). As a result of this luteal regression the exudation from the ovarian capillaries decreases and the volume as well as the protein content of the peritoneal fluid decline. This last phase of the menstrual cycle, however, was not investigated in the present study.

The results of the present investigation into the formation of peritoneal fluid indicate a striking resemblance with the mechanisms reported in the literature to be involved in the production of follicular fluid (Edwards, 1974, Andersen et al., 1976). Both appear to result from increased diffusion of fluid from the extracellular space, due to an increase in clearance of proteins from the ovarian capillaries. Follicular fluid and peritoneal fluid are exudation products of the ovarian capillaries. The exudation process increases as the vascularity of the dominant ovarian structures increases. The determining factor of the filtration process is most probably not the ovarian tissue as such, but the menstrual cycle-dependent vascularization of the ripening follicle and subsequently the corpus luteum.

\section{References}

Andersen, M.M., Krøll, J., Byskov, A.G. \& Faber, M. (1976) Protein composition in the fluid of individual bovine follicles. J. Reprod. Fert. 48, 109-118.

Bissell, D. (1932) Observations on the cyclical peivic fluid in the female. Am. J. Obstet. Gynec. 24, 271-273.

Bouckaert, P.X.J.M., van Wersch, J.W.J., Schellekens, L.A., Evers, J.L.H. \& Rolland, R. (1984) Haemostatic and fibrinolytic properties of peritoneal fluid in the menstrual cycle. Br. J. Obstet. Gynaec. 91, 256-259.

Coulam, C.B., Hill, L.M. \& Breekle, R. (1982) Ultrasonic evidence for luteinization of unruptured preovulatory follicles. Fert. Steril. 37, 524-529.

Doyle, J.B. (1951) Exploratory culdotomy for observation of tubo-ovarian physiology at ovulation time. Fert. Steril. 2, 475-486.

Edwards, R.G. (1974) Follicular fiuid. J. Reprod. Fert. 37, 189-219.

Hilgers, T.W., Abraham, G.E. \& Cavanagh, D. (1978) Natural family planning. I. The peak-symptom and estimated time of ovulation. Obstet. Gynecol. 52, 575-582.

Kaplan, A. \& Savory, J. (1965) Evaluation of a celluloseacetate electrophoresis system for serum protein fractionation. Clin. Chem. 11, 937-942.
Koninckx, P.R., Ranaer, M. \& Brosens, I.A. (1980a) Origin of peritoneal fluid in women: an ovarian exudation product. Br. J. Obstet. Gynaec. 87, 177-183.

Koninckx, P.R., de Moor, P. \& Brosens, I.A. (1980b) Diagnosis of the luteinized unruptured follicle syndrome by steroid hormone assays on peritoneal fluid. Br.J. Obstet. Gynaec. 87, 929-934.

Maathuis, J.B., Houx, P.C.W., Bastiaans, L.A. \& Mastboom, J.L. (1973) Some properties of peritoneal fluid obtained by laparoscopy from fertile and infertile women. J. Reprod. Fert. 35, 630-632.

Maathuis, J.B., Van Look, P.F.A. \& Michie, E.A. (1978) Changes in volume, total protein and ovarian steroid concentrations of peritoneal fluid throughout the human menstrual cycle. J. Endocr. 76, 123-133.

Mancini, G., Carbonara, A.O. \& Heremans, J.F. (1965) Immunochemical quantitation of antigens by single radial immunodiffusion. Immunochemistry 2, 235-254.

McNatty, K.P. \& Baird, D.T. (1978) Relationship between follicle stimulating hormone, androstenedione and oestradiol in human follicular fluid. $J$. Endocr. 76, 527-531. 
Moor, R.M., Hay, M.F. \& Seamark, R.F. (1975) The sheep ovary: regulation of steroidogenic, haemodynamic and structural changes in the largest follicle and adjacent tissue before ovulation. J. Reprod. Fert. 45, 595-604.

Novak, J. (1922) Uber Ursache und Bedeutung des physiologischen Ascites beim Weibe. Zentbl. Gynaek. 21, 854-858.

Peters, H. \& McNatty, K.P. (1980) Ovarian hormones. In The Ovary, pp.44-58. Eds H. Peters \& K. P. McNatty. Granada Publishing, London.

Richterich, R. (1971) Gesamt Proteïn: Biuret-Methode. In Klinische Chemie, pp. 305-309. Eds R. Richterich \& J. P. Colombo. S. Karger, Basel.

Scanes, C.G., Mozelic, H., Kavanagh, E., Merill, G. \& Rabii, J. (1982) Distribution of blood flow in the ovary of domestic fowl (Gallus domesticus) and changes after prostaglandin $\mathrm{F}$ treatment. $J$. Reprod. Fert. 64, 227-231.
Stähler, E., Spätling, L., Daume, E. \& Buchhol, R. (1977) Untersuchungen über das Verhalten des intrafollikulären Druckes im Abhängigkeit vom Druck im ovarielen gefässystem im Gewebe. Durchgeführt an in vitro perfundierte menschlichen Ovarien. Arch. Gynaecol. 223, 41-53.

Swanston, J.A., McNatty, K.P. \& Baird, D.T. (1977) Concentration of prostaglandin $\mathrm{F}$ and steroids in the human corpus luteum. J. Endocr. 73, 115-122.

Treloar, A.E., Boynton, R.E., Behn, B.G. \& Brown, B.W. (1967) Variation of the human menstrual cycle through reproductive life. Int. J. Fertil. 12, 77-126.

Zachariae, F. \& Jensen, C.E. (1958) Studies on the mechanism of ovulation: histochemical and physicochemical investigations on genuine follicular fluids. Acta endocr., Copenh. 27, 343-355.

Received 8 July 1985 